\title{
Understory Vegetation in Old-Growth and Second- Growth Tsuga Canadensis Forests in Western Massachusetts
}

\section{Citation}

D'Amato, Anthony W., David A. Orwig, and David R. Foster. 2009. Understory vegetation in oldgrowth and second-growth Tsuga canadensis forests in western Massachusetts. Forest Ecology and Management 257(3): 1043-1052.

\section{Published Version}

doi:10.1016/j.foreco.2008.11.003

\section{Permanent link}

http://nrs.harvard.edu/urn-3:HUL.InstRepos:4317710

\section{Terms of Use}

This article was downloaded from Harvard University's DASH repository, and is made available under the terms and conditions applicable to Open Access Policy Articles, as set forth at http:// nrs.harvard.edu/urn-3:HUL.InstRepos:dash.current.terms-of-use\#OAP

\section{Share Your Story}

The Harvard community has made this article openly available.

Please share how this access benefits you. Submit a story.

\section{Accessibility}


1 RUNNING HEAD: Old-growth forest understories

3 TITLE: Understory Vegetation in Old-Growth and Second-Growth Tsuga canadensis Forests in

4 Western Massachusetts

5

6 AUTHORS:

7 Anthony W. D’Amato ${ }^{1,2,3^{*}}$

8 David A. Orwig ${ }^{2}$

9 David R. Foster ${ }^{2}$

10

$11{ }^{1}$ Department of Forest Resources, University of Minnesota, St. Paul, MN 55108

$12 \quad{ }^{2}$ Harvard Forest, Harvard University, 324 N. Main St., Petersham, MA 01366

$13{ }^{3}$ Department of Natural Resources Conservation, University of Massachusetts, Amherst, MA

1401003.

15 *Corresponding author:

16 Dept. of Forest Resources

17 University of Minnesota

18115 Green Hall

191530 Cleveland Avenue North

20 St. Paul, MN 5508

21 damato@umn.edu

22

23 


\section{ABSTRACT}

2 We compared the understory communities (herbs, shrubs, and tree seedlings and saplings) of

3 old-growth and second-growth eastern hemlock forests (Tsuga canadensis) in western

4 Massachusetts, USA. Second-growth hemlock forests originated following clearcut logging in

5 the late 1800s and were 108 to 136 years old at the time of sampling. Old-growth hemlock

6 forests contained total ground cover of herbaceous and shrub species that was approximately 4

7 times greater than in second growth forests $\left(4.02 \pm 0.41\right.$ versus $\left.1.06 \pm 0.47 \% / \mathrm{m}^{2}\right)$ and supported

8 greater overall species richness and diversity. In addition, seedling and sapling densities were

9 greater in old-growth stands compared to second-growth stands and the composition of these

10 layers was positively correlated with overstory species composition (Mantel tests, $r>0.26, P<$

11 0.05) highlighting the strong positive neighborhood effects in these systems. Ordination of study

12 site understory species composition identified a strong gradient in community composition from

13 second-growth to old-growth stands. Vector overlays of environmental and forest structural

14 variables indicated that these gradients were related to differences in overstory tree density,

15 nitrogen availability, and coarse woody debris characteristics among hemlock stands. These

16 relationships suggest that differences in resource availability (e.g., light, moisture, and nutrients)

17 and microhabitat heterogeneity between old-growth and second-growth stands were likely

18 driving these compositional patterns. Interestingly, several common forest understory plants,

19 including Aralia nudicaulis, Dryopteris intermedia, and Viburnum alnifolium, were significant

20 indicator species for old-growth hemlock stands, highlighting the lasting legacy of past land use

21 on the reestablishment and growth of these common species within second-growth areas. The

22 return of old-growth understory conditions to these second-growth areas will largely be 
1 dependent on disturbance and self-thinning mediated changes in overstory structure, resource

2 availability, and microhabitat heterogeneity.

3 KEYWORDS: Tsuga canadensis, understory vegetation, old-growth, Massachusetts,

4 neighborhood effects, species diversity

\section{Introduction}

The understory layer is a critical component of forest ecosystems typically supporting the

8 vast majority of total ecosystem floristic diversity (Halpern and Spies 1995, Gilliam and Roberts

9 2003) and providing habitat elements to associated wildlife species (Carey and Johnson 1995).

10 These communities also play a central role in the dynamics and functioning of forest ecosystems

11 by influencing long-term successional patterns (Philips and Murdy 1995, Abrams and Downs

12 1990, Oliver and Larson 1996, McCarthy et al. 2001, Royo and Carson 2005, Nyland et al. 2006)

13 and contributing to forest nutrient cycles (Chapin 1983, Zak et al. 1990, Anderson and Eickmeier

14 2000, Chastain et al. 2006). Due to the recognized ecological importance of forest understory

15 plants, considerable effort has been devoted to determining the impacts of land-use practices on

16 the structure and diversity of these communities (Whitney and Foster 1988, Matlack 1994,

17 Motzkin et al. 1996, Bellemare et al. 2002, Eberhardt et al. 2003, Goslee et al. 2005; Fraterringo

18 et al. 2006, see also Ecological Applications Special Feature Vol. 5, 1995). This work has

19 demonstrated the importance of past land use in shaping contemporary patterns of understory

20 vegetation and has indicated that distinct community assemblages may characterize various

21 stages of forest succession.

22 Understory communities in old-growth forest ecosystems are often quite distinct relative

23 to forests originating following agricultural clearing or forest harvesting (Whitney and Foster 
1 1988, Matlack 1994, Qian et al 1997, Goebel et al. 1999). Although the diversity of understory

2 plants may be low in some old-growth systems (Metzger and Shultz 1984, Scheller and

3 Mladenoff 2002), other studies have indicated that certain taxa may be more abundant or

4 restricted to these forests (Whitney and Foster 1988, Matlack 1994, Halpern and Spies 1995,

5 Moola and Vasseur 2004). The affinity of certain species to old-growth forests has been

6 attributed to several factors, including reproductive characteristics of the plants (Peterken and

7 Game 1984, Matlack 1994, Meier et al. 1995), and characteristics of the environment in old-

8 growth forests, including favorable substrates (e.g., coarse woody debris, pit and mound

9 topography) and microclimatic conditions (e.g., deeply shaded microsites), that are typically less

10 common or absent from second-growth systems (Harmon and Franklin 1989, Peterson and

11 Campbell 1993, Chen et al. 1995, McGee and Kimmerer 2002). As a result of the reproductive

12 limitations and unique microhabitat requirements of some old-growth plant species, the

13 conservation of old-growth forest ecosystems may be of critical importance for the maintenance

14 of viable populations of certain plant species, particularly in landscapes highly fragmented by a

15 history of intensive land use (Meier et al. 1995). In addition, the maintenance of late-

16 successional understory plant communities is becoming an increasingly common forest

17 management objective creating a greater need for an understanding of the environmental

18 conditions promoting the abundance of these species (Alaback 1984, Bailey et al. 1998, Lindh

19 and Muir 2004).

20 Old-growth forests are extremely scarce on the landscapes of southern New England

21 constituting roughly $0.1 \%$ of the forested land base of states such as Massachusetts (D'Amato et

22 al. 2006). Numerous studies in this region have demonstrated differences in understory

23 community composition between secondary and primary forests (i.e., forests originating 
1 following agricultural clearing versus logging exclusively, Motzkin et al. 1996, Donahue et al.

2 2000, Bellemare et al. 2002); however, our understanding of the compositional differences that

3 may exist between old-growth and primary forests is fairly limited (but see Whitney and Foster

4 1988, Cooper-Ellis 1998). This study compares the understory vegetation of the few remaining

5 old-growth forests in western Massachusetts with adjacent second-growth forests that originated

6 following logging in the late $19^{\text {th }}$ Century, but were never cleared for agricultural purposes.

7 Many of the old-growth forests in western Massachusetts are surrounded by compositionally

8 similar second-growth stands providing the opportunity to investigate the influence of differing

9 past land-use on the understory communities of forests with similar overstory species

10 composition and edaphic and landscape settings. In addition, the majority of these old-growth

11 forests are dominated by eastern hemlock (Tsuga canadensis), a species currently threatened by

12 the introduced hemlock woolly adelgid (Adelges tsugae, HWA, Orwig and Foster 1998).

13 Although none of these forests are currently infested by HWA, this introduced pest is within 3

$14 \mathrm{~km}$ of several old-growth stands (C. Burnham, unpublished data). As a result, studies

15 characterizing the floristic composition of the understory layer prior to HWA infestation will

16 serve as an important baseline for monitoring the response of these ecosystems to this novel

17 disturbance (Small et al. 2005; Eschtruth et al. 2006, Cleavitt et al. 2008). Similarly, the

18 regeneration dynamics and floristic diversity of hemlock-dominated old-growth stands

19 throughout the range of this species have been dramatically influenced by herbivory stemming

20 from overabundant white-tail deer (Odocoileus virginianus) populations (Anderson and Loucks

21 1979, Frelich and Lorimer 1985, Alverson et al. 1988, Mladenoff and Stearns 1993, Rooney and

22 Dress 1997, Long et al. 1998, Weckel et al. 2006). The lack of similar high populations within

23 our study region provides an important opportunity to assess the structure and composition of 
1 systems currently unaffected by this conservation and management issue facing hemlock forests

2 in many other regions of North America (Rooney et al. 2000).

4 2. Materials and Methods

5 2.1. Study area

6 Sampling was conducted in 16 old-growth and 8 second-growth hemlock forests in the

7 Berkshire Hills and Taconic Mountains of western Massachusetts (Table 1). This area has a

8 humid, continental climate with average annual levels of precipitation ranging from 116.2 to

$9 \quad 129.5 \mathrm{~cm}$ and mean monthly temperatures from $-7.7^{\circ} \mathrm{C}$ in January to $22.2^{\circ} \mathrm{C}$ in July (NCDC

10 2006). Study areas were located on steep slopes (range: $25-41^{\circ}$ ) and ranged in elevation from

$11 \quad 305-685$ m.a.s.l. Soils in these areas are predominantly well-drained sandy loam soils formed

12 from weathered gneiss, schist, and phyllite (Zen et al. 1983, Scanu 1988).

13 Old-growth and second-growth status was assigned based on extensive analysis of

14 historical and dendroecological evidence collected from these areas (D'Amato et al. 2006).

15 Based on these analyses, old-growth areas were classified as sites lacking any evidence of past

16 land-use and containing at least five old (> 225 years old) canopy trees per hectare (cf. McGee et

17 al. 1999). In contrast, early state documents indicated that several second-growth areas adjacent

18 to old-growth areas were clear-cut harvested in the 1870s-1900s (Avery and Slack 1926;

19 D'Amato and Orwig 2008). In addition, dendroecological analyses of second-growth areas

20 confirmed that all second-growth sites were clear-cut harvested between the 1870s-1900s as

21 dramatic release and recruitment pulses were observed in these stands during these decades

22 (D'Amato 2007). In contrast to second-growth stands found in other mountainous regions of

23 New England, there was little evidence that these areas were burned following clear-cut 
1 harvesting (c.f. Goodale and Aber 2001) Care was taken in the selection of second-growth sites

2 to ensure that the environmental settings (e.g., elevation, topographic position, slope steepness,

3 and aspect) were as similar to those of the old-growth hemlock stands as possible.

4

$5 \quad$ 2.2. Vegetation sampling

$6 \quad$ Vegetation sampling plots were part of a larger study examining the structure and

7 disturbance dynamics of old-growth and second-growth forests in western Massachusetts

8 (D'Amato and Orwig 2008, D'Amato et al. 2008). Depending on stand size, 3-5 0.04-ha plots

9 were established along transects orientated through the central portion of each study area and

10 permanently marked. Percent cover of all vascular herbaceous plants, shrubs, and tree seedlings

11 were estimated by species in eight $1-\mathrm{m}^{2}$ sub-plots randomly located within each 0.04-ha

12 sampling plot during May and June 2004. Seedling densities were also determined in these sub-

13 plots. A complete census of herbaceous and shrub species was made in each 0.04-ha sampling

14 plot to generate master species lists. This census was repeated in the late summer to ensure

15 species emerging following the initial vegetation sampling were accounted for. No additional

16 species were identified during these late summer censuses. Species and diameter at breast height

17 (DBH) was recorded for every tree (stems $\geq 1.37 \mathrm{~m}$ tall and $\geq 10 \mathrm{~cm} \mathrm{DBH})$ rooted within the

18 0.04-ha plots. In addition, all saplings (stems $\geq 1.37 \mathrm{~m}$ tall and $\leq 10 \mathrm{~cm} \mathrm{DBH}$ ) were tallied by

19 species. Measurements of forest floor environmental characteristics, including coarse woody

20 debris abundance, soil $\mathrm{pH}$, and nitrogen availability determined from mixed-bed cation and anion

21 resin bags were also made within each 0.04 ha plot. Methods used for sampling CWD and soil

22 characteristics are summarized in D'Amato et al. (2008) and D'Amato (2007). Species

23 nomenclature follows Gleason and Cronquist (1990). 


\subsection{Statistical analyses}

Percent cover of herbs and shrubs and seedling and sapling densities were averaged for

3 each study area and compared between old-growth and second-growth forests using Wilcoxon

4 rank-sum tests. In addition, average species richness (number of species in study area, S),

5 diversity (Shannon-Wiener index, $H^{\prime}$ ), and evenness ( $E$, Pielou 1969) of understory herbs and

6 shrubs were compared between old-growth and second-growth forests using the same procedure.

7 Multivariate tests for differences in the composition of understory vegetation (herbs, shrubs, and

8 seedlings) between old-growth and second-growth forests were conducted using multi-response

9 permutation procedures (MRPP) in PC-ORD version 4.28 (McCune and Mefford 1999). MRPP

10 is a non-parametric, randomization-based multivariate test of differences between groups that

11 compares the plots within a priori groups to a random allocation of plots (McCune and Grace

12 2002). Sørensen distances were used to calculate average within-group distances for MRPP.

13 Indicator species analysis (Dufrene and Legendre 1997) was used to describe how well certain

14 understory species differentiated between old-growth and second-growth forests.

15 Non-metric multidimensional scaling (NMS; McCune and Grace 2002) was used to

16 examine patterns in understory community composition within and among old-growth and

17 second-growth forests. As was the case for MRPP, NMS used Sørensen distances to calculate a

18 distance matrix for the 24 study areas. To reduce noise in the data set, species with fewer than 3

19 occurrences were removed from the data matrices (McCune and Grace 2002). The "slow-and-

20 thorough" autopilot mode of NMS in PC-ORD was used to generate solutions. This procedure

21 determines the optimal ordination solution by stepping down in dimensionality from a six-axis to

22 one-axis solution using 40 runs performed on real data followed by 50 Monte Carlo runs using

23 random data (McCune and Mefford 1999). Optimal dimensionality was based on the number of 
1 dimensions with the lowest stress (i.e., smallest departure from monotonicity in the relationship

2 between distance in the original space and distance in the reduced ordination space, McCune and

3 Grace 2002). For this study, the minimum stress configuration included 3 axes; however, the

4 two axes accounting for the most variability in the original data set are presented. The

5 relationship between understory community composition and environmental and forest structural

6 characteristics, including inorganic $\mathrm{N}$ availability, forest floor $\mathrm{C}: \mathrm{N}$ ratio, abundance of coarse

7 woody debris, and overstory tree density, were explored using the bi-plot function in PC-ORD

8 (McCune and Mefford 1999). Ordinations were rigidly rotated to place the environmental or

9 forest structural variable with the highest correlation with understory community composition on

10 the first axis. Average percent cover of herbs, shrubs, and seedlings were used for MRPP and

11 NMS. Relationships between species abundance and NMS axis scores were explored using

12 Kendall's tau statistic (SAS version 9.1, SAS Institute Inc. 2004).

13 Matrix correlation was used to evaluate the degree of association between various strata

14 (e.g., herbs and shrubs, seedlings, saplings, overstory trees) within hemlock stands using Mantel

15 tests in PC-ORD (McCune and Mefford 1999). These tests calculate the correlation between two

16 dissimilarity matrices, which were derived using Sørensen distances in this study. We were

17 particularly interested in the influence of the overstory tree community on the composition of the

18 understory, seedling and sapling layers (i.e., neighborhood effects sensu Frelich and Reich

19 1995). Therefore, an overstory tree community dissimilarity matrix was correlated against the

20 understory, seedling, and sapling layer matrices. Similarly, the seedling and sapling dissimilarity

21 matrices were correlated against each other to examine the degree of association between these

22 two strata. Probability levels for the Mantel tests were calculated using 1000 Monte Carlo

23 randomizations (McCune and Mefford 1999) and the overstory matrix was based on importance 
1 values for overstory species in each stand. Significance levels were set at $\alpha=0.05$ for all

2 analyses and experiment-wide probability levels were protected by a sequential Bonferroni

3 procedure (Rice 1989).

4

\section{3. Results}

6 3.1. Diversity and cover of understory herbs and shrubs

$7 \quad$ A total of 47 understory herb and shrub species was identified across the 24 hemlock

8 stands examined in this study (Table 2). Of the species identified, 29 occurred only in old-

9 growth hemlock stands; no species were restricted to second-growth hemlock stands (Table 2).

10 No non-native species were found in either old-growth or second-growth stands (Table 2).

11 Importantly, the greater number of species found within old-growth forests may be an artifact of

12 the sampling design, as there were twice as many old-growth study areas as second-growth.

13 Nonetheless, compared with second-growth stands, old-growth forests had approximately 4

14 times the amount of total ground cover of herbaceous and shrub species (4.02 \pm 0.41 versus 1.06

$15 \pm 0.47 \% / \mathrm{m}^{2}$ ) and supported greater overall species richness and diversity (Table 3). In contrast,

16 evenness of herb and shrub species was greater in second-growth stands due in large part to the

17 lower species richness in these systems (Table 3).

19 3.2. Tree seedlings and saplings

20 Densities of seedlings and saplings were greater in old-growth stands compared to

21 second-growth stands (Table 4). Acer pensylvanicum, Tsuga canadensis, and Betula spp. (B.

22 lenta and B. alleghaniensis combined) generally had the highest seedling densities in both old-

23 growth and second-growth forests, and A. pensylvanicum was the only species that occurred in 
1 all stands (Table 4). Most seedling species were found in both old-growth and second-growth

2 forests; however, Pinus strobus and Acer saccharum only occurred as seedlings in old-growth

3 stands. Seedling densities varied considerably between old-growth and second-growth forests as

4 T. canadensis, Picea rubens, and Betula spp. had higher densities in old-growth stands while

5 Acer rubrum had higher densities in second-growth stands (Table 4). Overall, the composition

6 of the seedling layer was positively associated with the composition of the overstory layer

7 (Mantel test, $r=0.27, P<0.05$ ), suggesting the successful establishment of overstory species

8 within the understory layer of these stands.

$9 \quad$ Tsuga canadensis had the highest sapling density across old-growth and second-growth

10 stands and was the only species found in the sapling layer of all hemlock stands investigated

11 (Table 4). A. penslyvanicum and Fagus grandifolia were generally more abundant in old-growth

12 versus second-growth stands (Table 4). Several species occurring as seedlings within a given

13 forest type were not observed as saplings (Table 4). For example, Pinus strobus and Betula

14 papyrifera saplings were not observed in old-growth stands despite the presence of these species

15 in the seedling layer and in the overstory (Table 4). Likewise, saplings of B. papyrifera and

16 Quercus rubra were not found in second-growth stands despite their presence in the seedling

17 layer of these systems. Nonetheless, composition of the sapling layer among hemlock stands was

18 positively correlated with the composition of the seedling layer (Mantel test, $r=0.29, P<0.05$ ).

19 In addition, there was a positive correlation between the composition of the sapling layer and the

20 composition of the overstory layer (Mantel test, $r=0.30$, respectively, $P<0.05$ ). Conversely,

21 sapling densities were negatively correlated with density of overstory trees (Kendall's tau = -

$220.53, P<0.05)$. 


\subsection{Understory layer composition}

Understory communities differed between old-growth and second-growth stands (Multi-

3 response permutation procedures $\{\mathrm{MRPP}\} ; \mathrm{A}=0.03, P<0.05)$; however, the small effect size

$4(\mathrm{~A}=0.03)$ derived from MRPP suggested that there was also a wide range of variation in

5 understory community composition within old-growth and second-growth stands, respectively

6 (McCune and Grace 2002). This was illustrated by the broad distribution of points for each of

7 these stand types in the ordination of understory vegetation (Figure 1), which explained 65.2\%

8 of the variation in the raw data (NMS ordination, final stress $=12.35$, final instability $=0.00001$ ).

9 Most of the variation in understory vegetation among stands was explained by Axis 1 (30.4\%),

10 which represented a gradient from sites with low overstory tree densities and high $\mathrm{NH}_{4}-\mathrm{N}$

11 availability in the negative portion of Axis 1 to higher density sites with lower levels of available

$12 \mathrm{NH}_{4}-\mathrm{N}$ in the positive portion (Figure 1). Correlations of species with this axis indicated that

13 there was greater abundance of the fern species, Polypodium virginianum $(\tau=-0.55)$ and

14 Dryopteris intermedia $(\tau=-0.52)$, within old-growth study sites located in the negative portion

15 of Axis 1 (Figure 1, Table 5).

16 The distribution of study areas along Axis 2, which explained $27.8 \%$ of the variation,

17 generally ranged from sites with a smaller proportion of the total downed coarse woody debris

18 (CWD) pools in decay class IV (highly decayed, cf. Fraver et al. 2002) to sites with higher

19 proportions of this deadwood type (Figure 1). Study sites with downed woody debris pools

20 containing a higher proportion of wood in advanced stages of decay tended to have greater

21 amounts of Kalmia latifolia and Tsuga candensis in the understory as there was a significant

22 positive correlation between the abundance of these species and Axis 2 (Table 5). Importantly,

23 average volumes of decay class IV downed CWD were more than 9 times greater in old-growth 
1 stands compared to second-growth stands ( $21.3 \pm 7.7$ vs. $2.2 \pm 0.9 \mathrm{~m}^{3} / \mathrm{ha}$ in old-growth and

2 second-growth stands, respectively). Furthermore, total volumes of downed CWD were four

3 times as high in the old-growth stands examined in this study (D'Amato et al. 2008).

4 Despite the wide range of variation in understory community composition within both

5 old-growth and second-growth stands (based on MRPP), Indicator Species Analysis identified

6 four species indicative of the understory layer in old-growth hemlock forests relative to second-

7 growth stands: Dryopteris intermedia, Viburnum alnifolium, Aralia nudicaulis, and Tsuga

8 canadensis (Figure 2). Several other species, including Lycopodium lucidulum, Polypodium

9 virginianum, and Polystichum acrostichoides, were also more common in old-growth stands

10 (Figure 2). In contrast, only Acer rubrum seedlings were more common in second-growth stands

11 (Figure 2). There was no significant relationship between the composition of understory herbs

12 and shrubs and the composition of overstory trees among hemlock stands (Mantel test, $r=0.02$,

$13 \quad P=0.37)$.

\section{4. Discussion}

16 This study indicates that, despite compositional similarities in overstory trees, differences

17 exist between the understory communities characterizing old-growth and second-growth

18 hemlock forests in western Massachusetts. In particular, old-growth forests had higher species

19 richness and diversity, as well as a greater abundance of understory herbs and shrubs, and tree

20 seedlings and saplings compared to second-growth forests. The observed importance of

21 overstory tree density, nitrogen availability, and coarse woody debris characteristics in

22 explaining the variation in understory composition among hemlock stands suggests that 
1 differences in resource availability (e.g., light, moisture, and nutrients) and microhabitat

2 heterogeneity between old-growth and second-growth stands were likely driving these patterns.

4 4.1. Diversity and Abundance of Understory Herbs and Shrubs

Overstory tree density strongly influences patterns of understory species richness and

6 abundance (Alaback 1982, Peet and Christensen 1988, Oliver and Larson 1996). Several studies

7 have demonstrated that lower levels of species richness and abundance characterize dense,

8 closed canopy forests within the stem exclusion phase of development (sensu Oliver 1981,

9 Alaback 1982, Halpern 1988, Schoonmaker and McKee 1988, Eycott et al. 2006, Jules et al.

10 2008), whereas richness and abundance often increase as forests mature and self-thinning and

11 gap-scale disturbances create and maintain canopy openings (Davison and Forman 1982,

12 Alaback and Hermain 1988 Eycott et al. 2006). In this study, the second-growth stands we

13 examined were primarily in the stem exclusion phase of development, and the low sapling

14 densities and understory plant abundance and richness observed in these systems were likely a

15 reflection of the lower levels of resource availability (e.g., light, nutrients) in the understory layer

16 during this stage of stand development (Klinka et al. 1996, Oliver and Larson 1996). In contrast,

17 the structure of the old-growth areas had been primarily influenced by more than three centuries

18 of small to moderate gap-scale disturbances (D'Amato and Orwig 2008) resulting in stands

19 characterized by lower tree densities, larger trees, multi-layered canopies, and an abundance of

20 downed coarse woody debris and canopy gaps (D’Amato et al. 2008). Presumably, the diversity

21 of microhabitats and greater levels of resource availability associated with these structural

22 attributes (Alaback 1982, Oian et al. 1997, D'Amato 2007) and disturbance processes (Beatty

23 1984, Moore and Vankat 1986, Peterson et al. 1990, Reader and Bricker 1992) resulted in a 
1 greater abundance and richness of understory plants within old-growth stands compared to dense

2 second-growth stands.

3 Overall, the composition and abundance of understory plants among hemlock stands in

4 this study were similar to those reported elsewhere for second-growth (Rogers 1980, Eschtruth et

5 al. 2006) and old-growth hemlock forests (Whitney and Foster 1988). While the old-growth

6 stands in this study had a greater abundance of understory herb and shrubs compared to second-

7 growth, these values were much lower than those reported for other forest types in the region

8 (e.g., Rogers 1980, Gilliam et al. 1995). The sparse nature of understory vegetation within these

9 systems is likely a reflection of the low levels of nutrient and light availability, as well as higher

10 forest floor and soil acidity levels typically characterizing hemlock-dominated forests relative to

11 other forest types such as northern hardwood forests (Rogers 1980, Mladenoff 1987, Canham et

12 al. 1994, Lovett et al. 2004). Although these understory conditions limit the abundance of

13 understory herbs and shrubs, they tend to favor the establishment of conspecific regeneration

14 within hemlock-dominated stands (i.e., positive overstory-understory neighborhood effects,

15 Frelich and Reich 1995). These positive neighborhood effects between overstory trees and

16 understory regeneration were illustrated by the strong, positive associations in Mantel tests

17 conducted between overstory composition and the composition of the seedling and sapling layers

18 within the hemlock stands examined in this study. Correspondingly, management approaches

19 aimed at restoring old-growth characteristics to existing second-growth hemlock systems should

20 rely on selection systems that not only emulate the gap-scale disturbance regimes historically

21 characterizing these systems (c.f. D'Amato and Orwig 2008) but also maintain the understory

22 conditions favoring long-term hemlock establishment and recruitment (Brissette and Kenefic

23 2000). 
Several species were more abundant in old-growth than second-growth hemlock

2 understories, including Aralia nudicaulis, Dryopteris intermedia, and Viburnum alnifolium.

3 Several other studies examining the composition of old-growth, primary, and secondary forests

4 in the northeastern United States have also indicated that these species were more abundant in

5 old-growth and primary forest ecosystems (Nichols 1913, Egler 1940, Whitney and Foster 1988,

6 Motzkin et al. 1999, Singleton et al. 2001). For example, the occurrence of A. nudicaulis and $V$.

7 alnifolium was much greater in old-growth white pine-hemlock forests as compared to secondary

8 white pine-hemlock forests in central New England (Whitney and Foster 1988). These patterns

9 were attributed to the sensitivity of these species to competitive displacement and microclimatic

10 changes following forest harvesting, as well as to the dispersal and colonization limitations of $V$.

11 alnifolium (Whitney and Foster 1988, Motzkin et al. 1999). In contrast, the lack of suitable

12 microhabitats in secondary forests was suggested as a possible explanation for the greater

13 frequency of Dryopteris intermedia in primary forests compared to post-agricultural forests in

14 central New York (Singleton et al. 2001). Although we did not directly examine dispersal rates

15 or microhabitat associations in this study, it is likely that these mechanisms (e.g., dispersal

16 limitations, lack of suitable microhabitats, Meier et al. 1995) were influencing the differences in

17 abundance of these species between old-growth and second-growth hemlock forests. In

18 particular, A. nudicaulis and V. alnifolium spread primarily by vegetative means (Edwards 1984,

19 Nyland et al. 2006) and this reliance on clonal spread may have limited their ability to re-

20 colonize second-growth areas following harvesting (cf. Meier et al. 1995). Likewise, the lower

21 abundance of suitable microhabitats observed among second-growth hemlock stands (e.g.,

22 decayed logs, McGee 2001, D’Amato et al. 2008) may have contributed to the lower abundance

23 of $D$. intermedia in these systems. An additional possible explanation for the absence or lower 
1 abundance of these species in second-growth areas is that these species were never present in

2 these stands prior to harvesting. Despite this consideration, the historical ubiquity of these plant

3 species throughout these landscapes makes this explanation highly unlikely (Egler 1940). Due to

4 affinity of these species to old-growth and primary forests found in this and other studies in the

5 region, the abundance of these species might serve as useful indicators for evaluating the success

6 of management strategies aimed at restoring old-growth characteristics to second-growth

7 hemlock systems.

9 4.2. Composition and Abundance of Tree seedlings and Saplings

10 The high densities of Tsuga canadensis and Acer pensylvanicum seedlings observed in

11 old-growth and second-growth stands in this study were consistent with the findings of other

12 studies quantifying seedling densities in hemlock-dominated forests (e.g., Rogers 1980, Yorks et

13 al. 2000, Kizlinski et al. 2002) and was likely due to the ability of both these species to survive in

14 the low light levels and acidic soils characterizing these ecosystems (Hibbs 1979, Burns and

15 Honkala 1990, Lei and Lechowicz 1990, Kobe et al. 1995). In contrast, the prolific seed

16 production and seed banking abilities of the mid-tolerant species, Betula lenta and B.

17 alleghaniensis, likely contributed to the abundance of these seedlings among hemlock study

18 areas as these species often dominate the seed banks of hemlock-dominated forests (Castovsky

19 and Bazzaz 2000, Yorks et al. 2000, Sullivan and Ellison 2006). While these species may

20 germinate under low light conditions, their survival in these stands is dependent on canopy gaps

21 that increase light availability in the forest understory (Carlton and Bazzaz 1998, Orwig and

22 Foster 1998, Webster and Lorimer 2005). This was demonstrated by the affinity of $B$.

23 alleghaniensis and $B$. lenta saplings to recent canopy gaps within the hemlock stands we 
1 sampled (A. W. D'Amato, personal observation), as well as by the tremendous increase of these

2 species observed in the sapling layer of hemlock forests defoliated by hemlock woolly adelgid

3 (Orwig and Foster 1998, Kizlinski et al. 2002, Stadler et al. 2005). Based on these findings from

4 infested stands in the region and the characteristics of the seedling layers in the present study, it

5 is highly likely that a similar increase in B. alleghaniensis and B. lenta will occur on these sites

6 when hemlock woolly adelgid reaches these areas.

$7 \quad$ Although there were compositional similarities in the seedling and sapling layers between

8 old-growth and second-growth hemlock stands (Table 4), densities of seedlings and saplings

9 were much greater in old-growth stands. The factors described as influencing the patterns for

10 understory herb and shrub abundance between old-growth and second-growth stands (e.g.,

11 greater diversity of microhabitats and resource availability in old-growth stands) also likely

12 contributed to the patterns in seedling and sapling densities. In particular, several studies have

13 demonstrated the importance of decaying logs on the forest floor as microhabitats for certain tree

14 species (Christy and Mack 1984, Harmon and Franklin 1989, Beach and Halpern 2001),

15 including T. canadensis and B. alleghaniensis (Mladenoff and Stearns 1993, Corinth 1995,

16 McGee 2001, Marx and Walters 2008). In this study, the abundance of highly decayed downed

17 wood (decay class III and IV combined, after Fraver et al. 2002) was almost five times greater in

18 old-growth forests compared to second-growth forests (56.2 vs. $\left.11.6 \mathrm{~m}^{3} / \mathrm{ha}\right)$. While we did not

19 specifically sample downed logs for seedling and sapling abundance, seedlings of $T$. canadensis

20 and Betula spp. were commonly observed on these substrates within our study areas (A.W.

21 D'Amato, personal observation, Figure 3). In addition, the association of T. canadensis with this

22 microhabitat was demonstrated by the positive correlation between proportion of highly decayed

23 downed coarse woody debris and T. canadensis abundance in the ordination of understory 
1 community composition (Figure 1). Due to the importance of deadwood substrates in these

2 systems, the deliberate felling and retention of canopy trees in harvest gaps should be integrated

3 into management strategies aimed at restoring old-growth conditions to second-growth hemlock

4 stands. Importantly, including these provisions for CWD creation at each harvest entry will be

5 critical for ensuring that a diversity of decay classes are present in these stands over time (cf.

6 D'Amato and Catanzaro 2007).

7 Beyond differences in microhabitat and resource availability, it is likely that the greater

8 sapling densities in old-growth stands were also related to the differences in the nature of

9 disturbance in these systems as compared to second-growth stands. Both of these systems have

10 experienced small to moderate canopy disturbances over the past century (D'Amato and Orwig

11 2008); however, the size of canopy gaps created in old-growth stands is generally greater due to

12 the larger overstory trees in these stands (cf. Dahir and Lorimer 1996). As a result, these stands

13 contain understory light conditions more favorable for the recruitment of mid-tolerant and

14 tolerant species into the sapling layer. Moreover, the extreme shade tolerance of $T$. canadensis

15 allows it to persist under low light levels in the forest understory for extended periods of time,

16 often exceeding a century (Godman and Lancaster 1990, A.W. D'Amato, personal observation).

17 Therefore, some of the hemlock saplings within old-growth stands likely recruited prior to the

18 establishment of the second-growth areas examined, thus contributing to the greater abundance

19 of this species within old-growth areas. These patterns reinforce the suitability of selection

20 systems for increasing hemlock regeneration in second-growth systems and restoring canopy

21 complexity through the creation of well-developed sapling layers.

22 Interestingly, several compositional and structural components extirpated from the

23 understory layer of hemlock stands in other regions of the northeastern United States due to 
1 overbrowsing by white-tail deer, including Taxus canadensis and abundant T. canadensis

2 saplings (Frelich and Lorimer 1985, Alverson et al. 1988, Rooney and Dress 1997, Long et al.

3 1998, Weckel et al. 2006), were commonly documented in the old-growth and second-growth

4 stands observed in this study. Due to the comparatively low deer densities in our study region

5 ( 10 per square mile, MassWildlife 2008), these results serve as an illustration of the dramatic

6 effect white-tail deer is having on the structure and dynamics of eastern hemlock forests in other

7 portions of this species' range and represent a baseline for assessing how future increases in deer

8 densities within western Massachusetts affect the conservation and management of these

9 systems. Moreover, recent results highlighting the positive interactive effects of canopy

10 disturbance due to hemlock woolly adelgid infestation and severity of deer browsing underscore

11 the importance of simultaneously monitoring the impacts of these and other disturbance agents

12 on the future plant community dynamics of these currently unaffected systems (Eschtruth and

13 Battles 2008).

\section{5. Conclusions}

16 The understory communities in the old-growth hemlock stands examined in this study are

17 distinctive from those in hemlock dominated stands originating following logging in the late $19^{\text {th }}$

18 century. Understory vegetation characteristics within these old-growth stands, including species

19 richness, herb and shrub cover, and seedling and sapling densities, are much greater than those

20 observed within the understories of second-growth areas due in large part to the greater resource

21 availability and microhabitat heterogeneity characterizing these systems. Notably, differences in

22 composition, richness, and diversity between old-growth and second-growth hemlock stands

23 resulted from either the absence or lower abundance of several common forest herbs and shrubs 
1 within second-growth stands and were not due to the presence of rare species in old-growth.

2 Despite the lack of old-growth obligate understory species in these stands, the understory

3 communities of these old-growth systems represent important habitat features on the landscape

4 providing greater levels of forage and cover for a variety of wildlife relative to second-growth

5 hemlock stands. The return of old-growth understory conditions to these second-growth areas

6 will be largely dependent on disturbance and self-thinning mediated changes in overstory

7 structure, resource availability, and microhabitat heterogeneity within these systems. As such,

8 management strategies, including the use of gap-based silvicultural systems and the creation and

9 retention of CWD, may serve as effective approaches for actively restoring these understory

10 conditions to second-growth stands. Although hemlock woolly adelgid is not present at any

11 hemlock stands examined in this study, our results suggest that the loss of hemlock from these

12 areas will lead to the tremendous increases in B. lenta and B. alleghaniensis observed in infested

13 hemlock forests in this region (Orwig and Foster 1998). More importantly, infestation of these

14 areas will irreversibly alter the composition and structure of the few remaining old-growth

15 forests in southern New England.

\section{Acknowledgements}

18 We thank Jessica Butler, Glenn Motzkin, Christian Foster, and Ben Ewing for assistance with

19 fieldwork. This work was supported by NSF grant DEB-0236897 and USDA Focus Funding

20 Grant 01-DG-11244225-037. In addition, A.W. D'Amato received funding from the A.W.

21 Mellon Foundation and Pisgah Fund at the Harvard Forest. Comments from Brenda McComb

22 greatly improved this manuscript. This publication is a product of the Harvard Forest LTER

23 project. 


\section{References}

2 Abrams, M.D., and J.A. Downs. 1990. Successional replacement of old-growth white oak by mixed mesophytic hardwoods in southwestern Pennsylvania. Canadian Journal of Forest

$4 \quad$ Research 20: 1864-1870.

5 Alaback, P.B. 1982. Dynamics of understory biomass in Sitka spruce-western hemlock

$6 \quad$ forests of southeast Alaska. Ecology 63: 1932-1948.

7 Alaback, P.B. 1984. Plant succession following logging in the Sitka spruce-western

8 hemlock forests of southeast Alaska: implications of management. USDA Forest

9 Service General Technical Report PNW-173.

10 Anderson, R.C., and O.L. Loucks. 1979. White-tail deer (Odocoileus virginianus) influence

11 on structure and composition of Tsuga canadensis forests. Journal of Applied

$12 \quad$ Ecology 16: 855-861.

13 Anderson, W.B., and W.G. Eickmeier. 2000. Nutrient resorption in Claytonia virginica L.:

14 implications for deciduous forest nutrient cycling. Canadian Journal of Botany 78 :

$15 \quad 832-839$.

16 Avery, J., and T. Slack. 1926. Map of Mohawk Trail State Forest. Massachusetts Dept. of 17 Conservation and Recreation, Amherst, MA.

18 Bailey, J.D., C. Mayrsohn, P.S. Doescher, E. St. Pierre, and J.C. Tappeiner. 1998. Understory vegetation in old and young Douglas-fir forests of western Oregon. Forest Ecology and

21 Beach, E.W., and C.B. Halpern. 2001. Controls on conifer regeneration in managed riparian forests: effects of seed source, substrate, and vegetation. Canadian Journal of Forest Research 31: 471-482. 
1 Bellemare, J., G. Motzkin, and D.R. Foster. 2002. Legacies of the agricultural past in the forested present: an assessment of the historical land-use effects on rich mesic forests. Journal of Biogeography 29: 1401-1420.

Brissette, J.C., and L.S. Kenefic. Eastern hemlock response to even- and uneven-age management in the Acadian forest: results from the Penobscot Experimental Forest longterm silviculture study. In McManus, K.A., K.S. Shields, and D.R. Souto, eds., Proceedings: Symposium on sustainable management of hemlock ecosystems in eastern North America. USDA Forest Service General Technical Report NE-267, Newtown Square, PA. pp 23-28.

Brooks, R.T. 2004. Early regeneration following the presalvage cutting of hemlock from hemlock-dominated stands. Northern Journal of Applied Forestry 21: 12-18.

Burns, R.M., and B.H. Honkala. 1990. Silvics of North America. USDA Forest Service Handbook 654.

Canham, C.D., A.C. Finzi, S.W. Pacala, and D.H. Burbank. 1994. Causes and consequences of resource heterogeneity in forests: interspecific variation in light transmission by canopy trees. Canadian Journal of Forest Research 24: 337-349.

Carlton, G.C., and F.A. Bazzaz. 1998. Regeneration of three sympatric birch species on experimental hurricane blowdown microsites. Ecological Monographs 68: 99-120.

Carey, A.B., and M.L. Johnson. 1995. Small mammals in managed, naturally young, and oldgrowth forests. Ecological Applications 5: 336-352.

Catovsky, S., and F.A. Bazzaz. 2000. The role of resource interactions and seedling regeneration in maintaining a positive feedback in hemlock stands. Journal of Ecology 88: $100-112$. 
1 Chapin, F.S. 1983. Nitrogen and phosphorous nutrition and nutrient cycling by evergreen and

2 deciduous understory shrubs in an Alaskan black spruce forest. Canadian Journal of

$3 \quad$ Forest Research 13: 773-781.

4 Chastain, R.A., W.S. Currie, and P.A. Townsend. 2006. Carbon sequestration and nutrient 5 cycling implications of the evergreen understory layer in Appalachian forests. Forest

$6 \quad$ Ecology and Management 231: 63-77.

7 Chen, J., J.F. Franklin, and T.A. Spies. 1995. Growing-season microclimatic gradients from

8 clearcut edges into old-growth Douglas-fir forests. Ecological Applications 5: 74-86.

9 Christy, E.J., and R.N. Mack. 1984. Variation in demography of juvenile Tsuga heterophylla

10 across the substratum mosaic. Journal of Ecology 72: 75-91.

11 Cooper-Ellis, S. 1998. Bryophytes in old-growth forests of western Massachusetts. Journal of 12 the Torrey Botanical Society 125: 117-132.

13 Corinth, R. L. 1995. Coarse woody debris and regeneration of eastern hemlock. In G. Mroz and 14 J. Martin, eds. Hemlock Ecology and Management. Department of Forestry, University 15 of Wisconsin-Madison. pp. 73-90.

16 Cleavitt, N.L., A.K. Eschtruth, J.J. Battles, and T.J. Fahey. 2008. Bryophyte response to eastern 17 hemlock decline caused by hemlock woolly adelgid infestation. The Journal of the Torrey $18 \quad$ Botanical Society 135: 12-25.

19 Curtis, J.T. 1959. The Vegetation of Wisconsin. An Ordination of plant communities, University

21 Dahir, S.E, and C.G. Lorimer. 1996. Variation in canopy gap formation among developmental stages of northern hardwood stands. Canadian Journal of Forest Research 26: 1875-1892. 
1 D'Amato, A.W., D.A. Orwig, and D.R. Foster. 2006. New estimates of Massachusetts old-

2 growth forests: Useful data for regional conservation and forest reserve planning.

$3 \quad$ Northeastern Naturalist 13: 495-506.

4 D'Amato, A.W. 2007. Structural attributes, disturbance dyanamics, and ecosystem properties of

5 old-growth forests in western Massachusetts. Dissertation, University of Massachusetts-

$6 \quad$ Amherst.

7 D'Amato, A.W., and P.C. Catanazaro. 2007. Restoring old-growth characteristics. University

8 of Massachusetts, Cooperative Extension Landowner Outreach Pamphlet, 18 pp.

9 D'Amato, A.W., and D.A. Orwig. 2008. Stand and landscape-level disturbance dynamics in

10 old-growth forest ecosystems in western Massachusetts. Ecological Monographs 78:

$11 \quad 507-522$.

12 D'Amato, A.W., D.A. Orwig, and D.R. Foster. 2008. The influence of successional processes

13 and disturbance on the structure of Tsuga canadensis forests. Ecological Applications

14 18: $1182-1199$.

15 Davison, S.E., and R.T.T. Forman. 1982. Herb and shrub dynamics in a mature oak forest: a

16 thirty-year study. Bulletin of the Torrey Botanical Club 109: 64-73.

17 Dufendre, M., and P. Legendre. 1997. Species assemblages and indicator species: a need for a

18 flexible asymmetrical approach. Ecological Monographs 67: 345-366.

19 Eberhardt, R., D.R. Foster, G. Motzkin, and B. Hall. 2003. Conservation of changing

20 landscapes: vegetation, land-use history, and fire on Cape Cod National Seashore.

$21 \quad$ Ecological Applications 13: 68-84.

22 Edwards, J. 1984. Spatial pattern and clone structure of the perennial herb, Aralia nudicaulis L.

23 (Araliaceae). Bulletin of the Torrey Botanical Club 111: 28-33. 
1 Egler, F. E. 1940. Berkshire Plateau vegetation, Massachusetts. Ecological Monographs 10: 145-192.

3 Eschtruth, A.K., N.L. Cleavitt, J.J. Battles, R.A. Evans, and T.J. Fahey. 2006. Vegetation

4 dynamics in declining eastern hemlock stands: 9 years of forest response to hemlock

5 woolly adelgid infestation. Canadian Journal of Forest Research 36: 1435-1450.

6 Eschtruth, A.K., and J.J. Battles. 2008. Deer herbivory alters forest response to canopy decline

$7 \quad$ caused by an exotic insect pest. Ecological Applications 18: 360-376.

8 Eycott, A.E., A.R. Watkinson, and P.M. Dolman. 2006. Ecological patterns of plant diversity in

9 a plantation managed by clearfelling. Journal of Applied Ecology 43: 1160-1171.

10 Fraver, S., R.G. Wagner, and M.Day. 2002. Dynamics of coarse woody debris following gap

11 harvesting in an Acadian forest of central Maine, USA. Canadian Journal of Forest

$12 \quad$ Research 32: 2094-2105.

13 Fraterrigo, J.M., M.G. Turner, and S.M. Pearson. 2006. Interactions between past land use, life14 history traits and understory spatial heterogeneity. Landscape Ecology 21: 777-790.

15 Frelich, L.E., and C.G. Lorimer. 1985. Current and predicted long-term effects of deer

16 browsing on hemlock forests in Michigan, USA. Biological Conservation 34: 99-120.

17 Frelich, L.E., and P.B. Reich. 1995. Neighborhood effects, disturbance and succession in

18 forests of the western Great Lakes Region. Ecoscience 2: 148-158.

19 Gleason, H.A., and A. Cronquist. 1991. Manual of vascular plants of northeastern United States 20 and adjacent Canada. New York Botanical Garden, Bronx, NY.

21 Godman, R.M., and K. Lancaster. 1990. Tsuga canadensis. In R. M. Burns and B. H. Honkala, 22 eds. Silvics of North America: Volume 1. USDA Forest Service Handbook 654. 
1 Goebel, P.C., D.M. Hix, and A.M. Olivero. 1999. Seasonal ground-flora patterns and site factor relationships of second-growth and old-growth south-facing forest ecosystems, southeastern Ohio, USA. Natural Areas Journal 19: 12-29.

Goodale, C.L. and J.D. Aber, 2001. The long-term effects of land-use history on nitrogen cycling in northern hardwood forests. Ecological Applications 11, 253-267.

Goslee, S.C., W.A. Niering, D.L. Urban, and N.L. Christensen. 2005. Influence of environment, history and vegetative interactions on stand dynamics in a Connecticut forest. Journal of the Torrey Botanical Society 132: 471-482.

Halpern, C.B. and T.A. Spies. 1995. Plant species diversity in natural and managed forests of the Pacific Northwest. Ecological Applications 5: 913-934.

Harmon, M.E., and J.F. Franklin. 1989. Tree seedlings on longs in Picea-Tsuga forests of Oregon and Washington. Ecology 70: 48-59.

Jules, M.J., J.O. Sawyer, and E.S. Jules. 2008. Assessing the relationships between stand development and understory vegetation using a 420 -year chronosequence. Forest Ecology and Management 255: 2384-2393.

Kizlinski, M.L., D.A. Orwig, R.C. Cobb, and D.R. Foster. 2002. Direct and indirect ecosystem consequences of an invasive pest on forests dominated by eastern hemlock. Journal of Biogeography 29: 1489-1503.

Klinka, K., H.Y.H Chen, Q. Wang, and L. de Montigny. 1996. Forest canopies and their influence on understory vegetation in early seral stands on West Vancouver Island. Northwest Science 70: 193-200.

Kobe, R.K., S.W. Pacala, J.A. Silander, C.D. Canham. 1995. Juvenile tree survivorship as a component of shade tolerance. Ecological Applications 5: 517-532. 
1 Lei, T.T., and M.J. Lechowicz. 1990. Shade adaptation and shade tolerance in saplings of three 2 Acer species from eastern North America. Oecologia 84: 224-228.

3 Lindh, B.C., and P.S. Muir. 2004. Understory vegetation in young Douglas-fir forests: does

$4 \quad$ thinning help restore old-growth composition? Forest Ecology and Management 192: $5 \quad 285-296$.

6 Long, Z.T., W.P. Carson, and C.J. Peterson. 1998. Can disturbance create refugia from 7 herbivores: an example with hemlock regeneration on treefall mounds. Journal of the $8 \quad$ Torrey Botanical Society 125: 165-168.

9 Lovett, G.M., K.C. Weathers, M.A. Arthur, and J.C. Schultz. 2004. Nitrogen cycling in a northern hardwood forest: do species matter? Biogeochemistry 67: 289-308.

11 Marx, L., and M.B. Walters. 2008. Survival of tree seedlings on different species of decaying 12 wood maintains tree distribution in Michigan hemlock-hardwood forests. Journal of 13 Ecology 96: 505-513.

14 Massachusetts Department of Fish and Game (MassWildlife). 2008. Deer hunting information. http://www.mass.gov/dfwele/dfw/recreation/hunting/deer/deer_hunting_home.htm Last

17 Matlack, G.R. 1994. Plant species migration in a mixed-history forest landscape in eastern $18 \quad$ North America. Ecology 75: 1491-1502.

19 McCarthy, B.C., C.J. Small, and D.L. Rubino. 2001. Composition, structure and dynamics of 20 Dysarts Woods, an old-growth mixed mesophytic forest of southeastern Ohio. Forest $21 \quad$ Ecology and Management 140: 193-213.

22 McCune, B., and J.B. Grace. 2002. Analysis of ecological communities. MjM Software Design. 23 Gleneden Beach, OR. 300 pp. 
1 McCune B., and M. J. Mefford. 1999. PC-ORD, multivariate analysis of ecological data, version 4.0. MjM Software Design, Gleneden Beach, Oregon, USA.

3 McGee, G.G., D.J. Leopold, and R.D. Nyland. 1999. Structural characteristics of old-growth, $4 \quad$ maturing, and partially cut northern hardwood forests. Ecological Applications 9: 13161329.

McGee, G.G. 2001. Stand-level effects on the role of decaying logs as vascular plant habitat in Adirondack northern hardwood forests. Journal of the Torrey Botanical Society 128:

Meier, A.J., S.P. Bratton, D.C. Duffy. 1995. Possible ecological mechanisms for loss of vernal-

McGee, G.G., and R.W. Kimmerer 2002. Forest age and management effects on epiphytic bryophyte communities in Adirondack northern hardwood forests, New York, USA. Canadian Journal of Forest Research 32: 1562-1576. herb diversity in logged eastern deciduous forests. Ecological Applications 5: 935-946.

Metzger, F., and J. Schultz. 1984. Understory response to 50 years of management of a northern hardwood forest in Upper Michigan. American Midland Naturalist 112: 209-223.

Miller, T.F., D.J. Mladenoff, and M.K. Clayton. 2002. Old-growth northern hardwood forests: spatial autocorrelation and patterns of understory vegetation. Ecological Monographs 72: 487-503.

Mladenoff, D.J. 1987. Dynamics of nitrogen mineralization and nitrification in hemlock and hardwood treefall gaps. Ecology 68: 1171-1180.

Mladenoff, D.J., and F. Stearns. 1993. Eastern hemlock regeneration and deer browsing in the northern Great Lakes region: a re-examination and model simulation. Conservation Biology 7: 889-900. 
1 Motzkin, G., D.R. Foster, A. Allen, J. Harrod, and R.D. Boone. 1996. Controlling site to

2 evaluate history: vegetation patterns of a New England sand plain. Ecological

3 Monographs 66: 345-365.

4 Motzkin, G., P. Wilson, D. R. Foster, and A. Allen. 1999. Vegetation patterns in heterogeneous

5 landscapes: the importance of history and environment. Journal of Vegetation Science 10:

$6903-920$.

7 National Climatic Data Center (NCDC). 2006. www.ncdc.noaa.gov/oa/ncdc.html

8 Nichols, G.E. 1913. The vegetation of Connecticut. II. Virgin forests. Torreya 13: 199-215.

9 Nyland, R.D., A.L. Bashant, K.K. Bohn, and J.M Verostek. 2006. Interference to hardwood

10 regeneration in northeastern North America: controlling effects of American beech,

11 striped maple, and hobblebush. Northern Journal of Applied Forestry 23: 122-132.

12 Qian, H., K. Klinka, and B. Sivak. 1997. Diversity of the understory vascular vegetation in 40

13 year-old and old-growth stands on Vancouver Island, British Columbia. Journal of

$14 \quad$ Vegetation Science 8: 773-780.

15 Oliver, C.D. 1981. Forest development in North America following major disturbances. Forest

$16 \quad$ Ecology and Management 3: 153-168.

17 Oliver, C. D., and B.C. Larson. 1996. Forest stand dynamics. John Wiley and Sons Inc. New

$18 \quad$ York, NY. 520pp.

19 Orwig, D.A., and D.R. Foster. 1998. Forest response to the introduced hemlock woolly adelgid in southern New England, USA. Journal of the Torrey Botanical Society 125: 60-73.

21 Peet, R.K., and N.L. Christensen. 1988. Changes in species diversity during secondary succession on the North Carolina Piedmont. In H.J. During, M.J.A. Derger, and J.H. 
Willems, eds., Diversity and pattern in plant communities. SPB Academic Publishing, the Hague. Pp. 233-245.

3 Peterken G.F. 1996. Natural woodland: ecology and conservation in northern temperate regions.

$4 \quad$ Cambridge University Press, Cambridge, UK. 522 pp.

5 Peterson, C.J., and J.E. Campbell. 1993. Microsite differences and temporal change in plant

6 communities of treefall pits and mounds in an old-growth forests. Bulletin of the Torrey

$7 \quad$ Botanical Club 120: 451-460.

8 Pielou, E.C. 1969. An introduction to mathematical ecology. John Wiley and Sons, New York.

9 Reader, R.J., and B.D. Bricker. 1992. Response of five deciduous forest herbs to partial canopy 10 removal and patch size. American Midland Naturalist 127: 149-157.

11 Rice, W. R. 1989. Analyzing tables of statistical tests. Evolution 43: 223-225.

12 Rogers, R.S. 1980. Hemlock stands from Wisconsin to Nova Scotia: transitions in understory 13 composition along a floristic gradient. Ecology 61: 178-193.

14 Rooney, T.P., and W.J. Dress. 1997. Species loss over sixty-six years in the ground-layer 15 vegetation of Heart's Content, an old-growth forests in Pennsylvania, USA. Natural $16 \quad$ Areas Journal 17: 297-305.

17 Rooney, T.P., R.J. McCormick, S.L. Solheim, and D.M. Waller. 2000. Regional variation in recruitment of hemlock seedlings and saplings in the upper Great Lakes, USA. Ecological Applications 10: 1119-1132.

Royo, A.A., and W.P. Carson. 2005. On the formation of dense understory layers in forests worldwide: consequences and implications for forest dynamics, biodiversity, and succession. Canadian Journal of Forest Research 36: 1345-1362. 
1 Scanu, R.J. 1988. Soil survey of Berkshire County, Massachusetts. United States Department of $2 \quad$ Agriculture, Soil Conservation Service. $217 \mathrm{pp}$.

3 Scheller, R.M., and D. J. Mladenoff. 2002. Understory species patterns and diversity in old$4 \quad$ growth and managed northern hardwood forests. Ecological Applications 12: 1329-1343.

5 Schoonmaker, P., and A. McKee. 1988. Species composition and diversity during secondary 6 succession of coniferous forests in western Cascade Mountains of Oregon. Forest $7 \quad$ Science 34: 960-979.

8 Singleton, R., S. Gardescu, P.L. Marks, and M.A Gerber. 2001. Forest herb colonization of 9 postagricultural forests in central New York State, USA. Journal of Ecology 89: 325$10 \quad 338$.

11 Small M.J., C.J. Small, G.D. Dreyer. 2005. Changes in a hemlock-dominated forest following woolly adelgid infestation in southern New England. The Journal of the Torrey Botanical

14 Stadler, B., T. Müller, D. Orwig, and R. Cobb. 2005. Hemlock woolly adelgid in New England Society $132: 458-470$

17 Sullivan, K.A., and A.M. Ellison. 2006. The seed bank of hemlock forests: implication for forest regeneration following hemlock decline. Journal of the Torrey Botanical Club 133: $393-402$.

Tyrrell, L.E., and T.R. Crow. 1994. Structural characteristics of old-growth hemlock-hardwood forests in relation to age. Ecology 75: 370-386.

22 Webster, C.R., and C.G. Lorimer. 2005. Minimum opening sizes for canopy recruitment of midtolerant species: a retrospective approach. Ecological Applications 15: 1245-1262. 
1 Weckel, M., J.M. Tirpak, C. Nagy, and R. Christie. 2006. Structural and compositional change in an old-growth eastern hemlock Tsuga canadensis forest, 1965-2004. Forest Ecology and Management 231: 114-118.

4 Whitney, G.G., and D.R. Foster. 1988. Overstorey composition and age as determinants of the

\section{Average}

\section{Percent canopy tree Elevation Slope Aspect}

$\begin{array}{lllllll}\text { Study site } & \text { Status }^{1} & \text { hemlock }^{2} & \text { age }^{3}(\mathrm{yr}) & (\mathrm{m}) & \left(^{\circ}\right) & \left(^{\circ}\right)\end{array}$

5 understorey flora of woods of central New England. Journal of Ecology 76: 867-876.

6 Yorks, T.E., D.J. Leopold, and D.J. Raynal. 2000. Vascular plant propagule banks of six eastern

7 hemlock stands in the Catskill Mountains of New York. Journal of the Torrey Botanical

$8 \quad$ Society $127: 87-93$.

9 Zak, D.R., P.M Groffman, K.S. Pregitzer, S. Christensen, and J.M. Tiedje. 1990. The vernal

10 dam: plant-microbe competition for nitrogen in northern hardwood forests. Ecology 71:

$11 \quad 651-656$.

12 Zen, E-an, G.R. Goldsmith, N.L. Ratcliffe, P. Robinson, and R.S. Stanley. 1983. Bedrock

13 geologic map of Massachusetts. United States Geological Survey, Monograph Series.

14 Ziegler, S.S. 2000. A comparison of structural characteristics between old-growth and post-fire

15 second-growth hemlock-hardwood forests in Adirondack Park, New York, U.S.A.

16 Global Ecology and Biogeography 9: 373-389. 


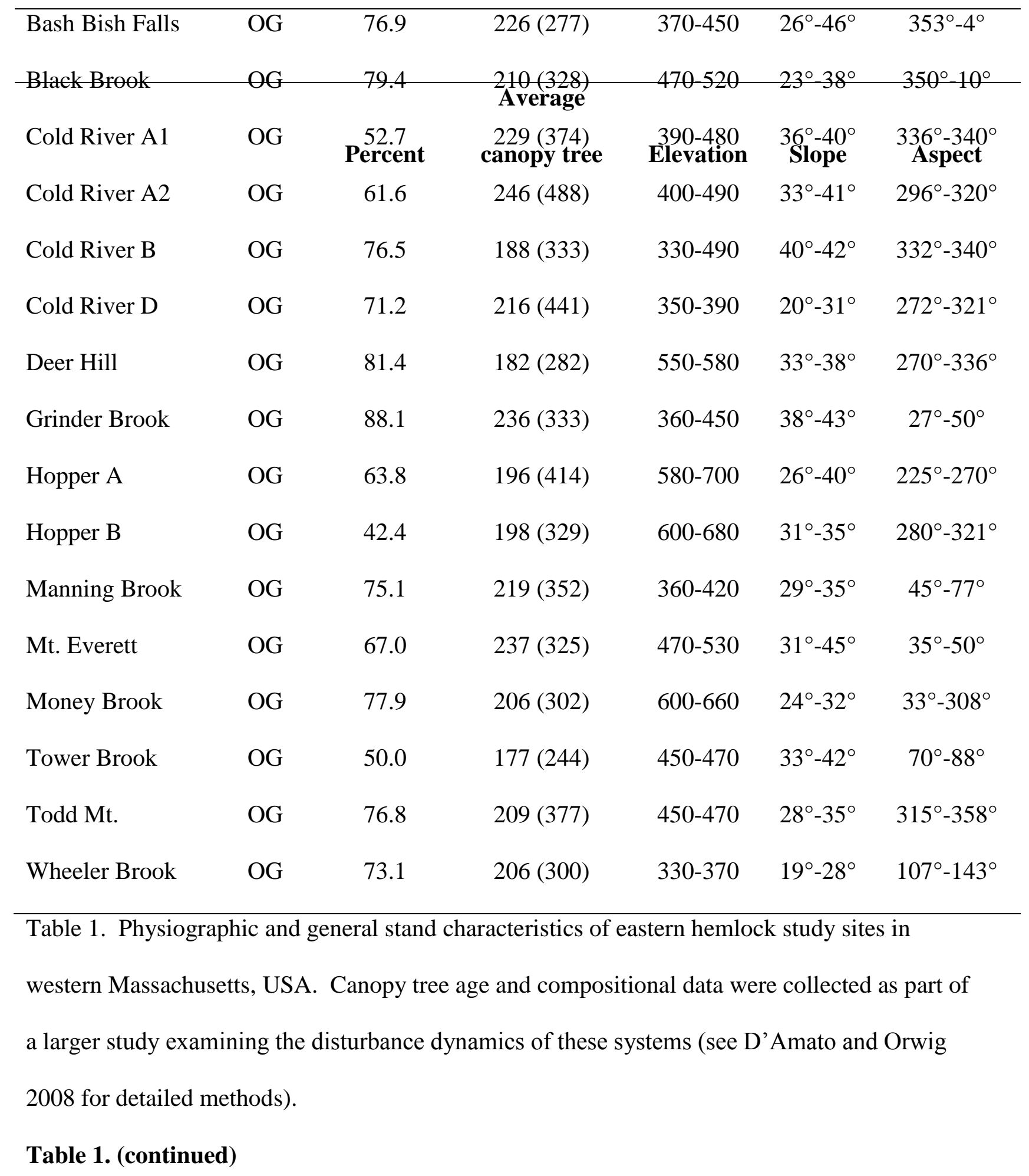




\begin{tabular}{|c|c|c|c|c|c|c|c|}
\hline & Study site & Status $^{1}$ & hemlock $^{2}$ & $\operatorname{age}^{3}(y r)$ & (m) & $\left({ }^{\circ}\right)$ & $\left(^{\circ}\right)$ \\
\hline & Bash Bish Falls & $2 \mathrm{G}$ & 70.0 & $115(171)$ & $380-430$ & $26^{\circ}-34^{\circ}$ & $325^{\circ}-350^{\circ}$ \\
\hline & Cold River A & $2 \mathrm{G}$ & 60.0 & $132(182)$ & $430-510$ & $29^{\circ}-36^{\circ}$ & $290^{\circ}-303^{\circ}$ \\
\hline & Cold River B & $2 \mathrm{G}$ & 69.8 & $108(270)$ & $340-380$ & $31^{\circ}-35^{\circ}$ & $255^{\circ}-290^{\circ}$ \\
\hline & Deer Hill & $2 \mathrm{G}$ & 52.5 & $113(216)$ & $500-540$ & $35^{\circ}-38^{\circ}$ & $350^{\circ}-0^{\circ}$ \\
\hline & Dunbar Brook & $2 \mathrm{G}$ & 72.6 & $136(204)$ & $380-410$ & $27^{\circ}-36^{\circ}$ & $45^{\circ}-68^{\circ}$ \\
\hline & Grinder Brook & $2 \mathrm{G}$ & 57.3 & $128(151)$ & $400-460$ & $25^{\circ}-46^{\circ}$ & $40^{\circ}-70^{\circ}$ \\
\hline & Money Brook & $2 \mathrm{G}$ & 70.5 & $133(201)$ & $590-620$ & $26^{\circ}-34^{\circ}$ & $260^{\circ}-290^{\circ}$ \\
\hline & Trout Brook & $2 \mathrm{G}$ & 63.0 & $136(323)$ & $320-370$ & $29^{\circ}-32^{\circ}$ & $330^{\circ}-340^{\circ}$ \\
\hline 1 & \multicolumn{7}{|c|}{${ }^{\mathrm{I}} \mathrm{OG}=$ old growth, $2 \mathrm{G}=$ second-growth } \\
\hline 2 & \multicolumn{7}{|c|}{${ }^{2}$ Importance value calculated as: ((Relative basal area) $+($ Relative Density) $) / 2$} \\
\hline 3 & \multicolumn{7}{|c|}{${ }^{3}$ Value in parentheses represents age of oldest tree with complete increment core sample } \\
\hline \\
\hline \multicolumn{8}{|c|}{6} \\
\hline \multicolumn{8}{|l|}{7} \\
\hline \multicolumn{8}{|l|}{8} \\
\hline \\
\hline \multicolumn{8}{|c|}{ 0 } \\
\hline \multicolumn{8}{|c|}{1} \\
\hline & & & & & & & \\
\hline & Table 2. Herb, g, & minoid, shr & ub, fern, and & b moss speci & dentified in & the underst & ry of old- \\
\hline
\end{tabular}


1 occurrences are based on complete censuses of 0.04-ha plots within each study area (3-5 plots

2 per site). Nomenclature follows Gleason and Cronquist (1991).

\begin{tabular}{|c|c|c|c|c|c|}
\hline Species & OG & $2 G$ & Species & OG & $2 G$ \\
\hline Herbs & & & Herbs (cont.) & & \\
\hline Actaea alba & $\mathrm{X}$ & & Monotropa uniflora & $\mathrm{X}$ & $X$ \\
\hline Aralia nudicaulis. & $\mathrm{X}$ & $\mathrm{X}$ & Oxalis acetosella & $X$ & \\
\hline Arisaema triphyllum. & $X$ & & Polygonatum pubescens & $X$ & \\
\hline Aster acuminatus. & $X$ & $X$ & Solidago flexicaulis & $X$ & \\
\hline Aster dumosus & $\mathrm{X}$ & & Tiarella cordifolia & $X$ & \\
\hline Aster divericatus & $\mathrm{X}$ & & Trientalis borealis & $\mathrm{X}$ & $\mathrm{X}$ \\
\hline Chimaphila maculate. & $\mathrm{X}$ & $\mathrm{X}$ & Trillium erectum & $\mathrm{X}$ & \\
\hline Circaea alpina & $X$ & $\mathrm{X}$ & Trillium undulatum & $X$ & $X$ \\
\hline Clintonia borealis & $\mathrm{X}$ & & Viola rotundifolia & $\mathrm{X}$ & \\
\hline Cypripedium acaule & $\mathrm{X}$ & & Graminoids & & \\
\hline Epigaea repens & $\mathrm{X}$ & $\mathrm{X}$ & Carex pensylvanica & $X$ & $\mathrm{X}$ \\
\hline Galium spp. & $\mathrm{X}$ & $\mathrm{X}$ & Ferns & & \\
\hline Gaultheria procumbens & $X$ & $X$ & Adiantum pedatum & $X$ & \\
\hline Laportea canadensis & $\mathrm{X}$ & & Dryopertis intermedia & $\mathrm{X}$ & $\mathrm{X}$ \\
\hline Maianthemum canadense & $\mathrm{X}$ & & Dryopteris marginalis & $\mathrm{X}$ & \\
\hline Medeola virginiana & $\mathrm{X}$ & & Polypodium virginianum & $X$ & \\
\hline Mitchella repens & $X$ & $\mathrm{X}$ & Thelypteris phegopteris & $X$ & \\
\hline
\end{tabular}

3 Table 2. (continued)

$\begin{array}{llllll}\text { Species } & \text { OG } & 2 \mathrm{G} & \text { Species } & \text { OG } & \text { 2G }\end{array}$




\begin{tabular}{lcccccc}
\hline Shrubs & & & Club mosses & & \\
Cornus alternifolia & $\mathrm{X}$ & & Lycopodium annotinum & $\mathrm{X}$ & \\
Hamamelis virginiana & $\mathrm{X}$ & $\mathrm{X}$ & Lycopodium lucidulum & $\mathrm{X}$ & $\mathrm{X}$ \\
Kalmia latifolia & $\mathrm{X}$ & $\mathrm{X}$ & Polystichum acrostichoides & $\mathrm{X}$ & $\mathrm{X}$ \\
Rhododendron canescens & $\mathrm{X}$ & & & & \\
Rubus allegheniensis & $\mathrm{X}$ & & & \\
Rubus idaeus & $\mathrm{X}$ & & & \\
Sambucus racemosa & $\mathrm{X}$ & & & \\
Solidago flexicaulis & $\mathrm{X}$ & & & \\
Taxus canadensis & $\mathrm{X}$ & & & \\
Vaccinium angustifolium & $\mathrm{X}$ & $\mathrm{X}$ & & \\
Viburnum acerifolium & $\mathrm{X}$ & & & \\
Viburnum alnifolium & $\mathrm{X}$ & $\mathrm{X}$ & & \\
\hline
\end{tabular}

9 Table 3. Mean cover and site-level species richness $(S)$, diversity $\left(H^{\prime}\right)$, and evenness $(E)$ of all 10 herbaceous (herbs, ferns, graminoids, and club mosses) and shrub species in old-growth and 
1 second-growth hemlock stands. Values are based on average cover and frequency of herb and

2 shrub species across understory subplots within each study area (1 $\mathrm{m}^{2}, 24-40$ per site) Standard

3 errors are in parentheses and means with different letters are significantly different $(P<0.05$,

4 Wilcoxon rank-sum test).

5

6

\begin{tabular}{llcc} 
& \multicolumn{2}{c}{$\begin{array}{c}\text { Old-growth }(\boldsymbol{n}=\mathbf{1 6}) \\
\text { Old-Growth }(\boldsymbol{n}=\mathbf{1 6})\end{array}$} & $\begin{array}{c}\text { Second-growth }(\boldsymbol{n}=\mathbf{8}) \\
\text { Second-Growth }\end{array}$ \\
\cline { 2 - 4 } & Plant cover $\left(\% / \mathrm{m}^{2}\right)$ & $4.02(0.41) \mathrm{a}$ & $1.06(0.47) \mathrm{b}$ \\
7 & Richness $(S)$ & $13.56(1.11) \mathrm{a}$ & $6.88(0.83) \mathrm{b}$ \\
8 & Diversity $\left(H^{\prime}\right)$ & $2.12(0.08) \mathrm{a}$ & $1.64(0.11) \mathrm{b}$ \\
9 & Evenness $(\mathrm{E})$ & $0.83(0.01) \mathrm{a}$ & $0.88(0.02) \mathrm{b}$ \\
\hline
\end{tabular}

10

11

12

13

14

15

16

17

18

19

20

21 


\begin{tabular}{lcccc}
\hline Species & Seedlings (\#/ha) & Saplings (\#/ha) & Seedlings (\#/ha) & Saplings (\#/ha) \\
\hline Acer pensylvanicum & $13747(417-7917)$ & $165(0-383)$ & $4688(417-13750)$ & $8(0-25)$ \\
Acer rubrum & $1371(0-7917)$ & $2(0-25)$ & $3177(0-12083)$ & $10(0-25)$ \\
Acer saccharum & $677(0-9167)$ & $18(0-300)$ & - & $1(0-8)$ \\
Betula alleghaniensis & - & $41(0-169)$ & - & $3(0-17)$ \\
Betula lenta & - & $74(0-442)$ & - & $20(0-67)$ \\
Betula spp ${ }^{1}$. & $5722(0-27083)$ & - & $2500(417-9167)$ & - \\
Betula papyrifera & $15(0-250)$ & - & $185(0-1667)$ & - \\
Fagus grandifolia & $820(0-3125)$ & $119(0-363)$ & $990(0-2917)$ & $66(0-200)$ \\
Picea rubens $^{\text {Pinus strobus }}$ & $1169(0-5313)$ & $36(0-275)$ & $52(0-417)$ & $9(0-75)$ \\
Quercus rubra $_{\text {Tsuga canadensis }}$ & $83(0-500)$ & - & - & - \\
Total $^{2}$ & $133(0-1250)$ & $1(0-8)$ & $313(0-1250)$ & - \\
\hline
\end{tabular}

1 Table 4. Average seedling and sapling densities (\#/ha) in old-growth and second-growth

2 hemlock forests. Ranges appear in parentheses for each species and standard errors are depicted

3 for totals. Totals with different letters indicate significant differences between old-growth and

4 second-growth stands $(P<0.05$, Wilcoxon Rank-Sum test). Species-level values represent site-

5 level averages, whereas totals represent averages across old-growth and second-growth stands,

6 respectively.

$7 \quad{ }^{1}$ Seedlings of Betula alleghaniensis and B. lenta were combined for estimates of seedling 8 density. 
$1 \quad{ }^{2}$ Includes less common species not listed in table, Fraxinus americana, Ostrya virginiana, Pinus

2 resinosa, Sorbus americana, and Tilia americana.

4 Table 5. Correlations (Kendall's $\tau$ ) between the average percent cover of understory herbs,

5 shrubs, and tree seedlings within each study area $\left(\% / \mathrm{m}^{2}\right)$ and non-metric multidimensional

6 scaling Axis 1 and 2. Species in bold have significant correlations with axes scores $(P<0.05$

7 (Bonferroni-protected).

\begin{tabular}{lcclcc}
\hline Species & Axis 1 & Axis 2 & Species & Axis 1 & Axis 2 \\
\hline Acer pensylvanicum & -0.17 & 0.07 & Mitchella repens & 0.04 & -0.27 \\
Acer rubrum & 0.45 & 0.34 & Monotropa uniflora & 0.20 & 0.29 \\
Acer saccharum & -0.42 & -0.08 & Oxalis acetosella & -0.44 & 0.10 \\
Acer spicatum & -0.39 & -0.02 & Picea rubens & -0.30 & 0.17 \\
Aralia nudicaulis & -0.41 & 0.13 & Polystichum acrostichoides & -0.27 & 0.03 \\
Aster acuminatis & -0.48 & 0.12 & Polypodium virginianum & $\mathbf{- 0 . 5 5}$ & 0.12 \\
Betula spp. & -0.33 & 0.41 & Quercus rubra & 0.40 & 0.21 \\
Dryopteris intermedia & $\mathbf{- 0 . 5 2}$ & -0.17 & Taxus canadensis & -0.42 & 0.01 \\
Fagus grandifolia & 0.19 & -0.23 & Trientalis borealis & -0.37 & 0.13 \\
Kalmia latifolia & 0.18 & $\mathbf{0 . 5 6}$ & Trillium undulatum & 0.05 & 0.32 \\
Lycopodium lucidulum & -0.39 & -0.11 & Tsuga canadensis & -0.37 & $\mathbf{0 . 5 0}$ \\
Maianthemum canadense & -0.18 & 0.14 & Viburnum alnifolium & -0.35 & 0.15 \\
\hline
\end{tabular}

